\title{
Çeşitli Makine Kısıtlarını İçeren Optimum Hücre Tasarım Problemi için Matematik Programlama Modeli
}

\author{
A Mathematical Programming Model for Optimum Cell Design Problem Involving Various \\ Machine Constraints
}

\author{
Onur DERSE ${ }^{1}$ (D), Ebru YILMAZ ${ }^{2}$ \\ ${ }^{1}$ Tarsus Üniversitesi, Meslek Yüksekokulu, Yönetim ve Organizasyon Bölümü, 33400, Tarsus, Mersin, Türkiye \\ ${ }^{2}$ Çukurova Üniversitesi, Mühendislik Fakültesi, Endüstri Mühendisliği Bölümü, 01330, Sarlçam, Adana, Türkiye
}

\begin{abstract}
$\ddot{\mathbf{O z}}$
Hücresel üretim sistemleri, firmaların sürekli gelişen teknolojiye ve rekabete adaptasyon sağlayabilmesi amaciyla kullanılan ve benzer işlemlerin benzer ortamlarda üretilmesi esasına dayalı olan sistemlerdir. Hücresel üretim sistemlerinin etkin bir şekilde kurulması ve tasarlanması ile işlemlerin daha hızlı ve daha az maliyetle gerçekleşmesi sağlanabilmektedir. Bu çalışmada, kalemleri, üretim maliyeti, makinelerin hazırlık maliyeti, makinelerin bakım maliyeti ve personel maliyeti olan en uygun toplam tasarım maliyetini hedefleyen bir matematik programlama modeli oluşturulmaktadır. Bu modelde, makinelerin kapasiteleri, hücreyi oluşturmak için gerekli olan en az makine sayısı, her makine türünün en fazla atanabileceği hücre sayısı, parçaların en az kaç makinede işlem görebileceği, parçaların en fazla kaç makinede işlem görebileceği ve parçaların hangi makinelerde işlem göremeyeceği gibi çeşitli kısıtlar dikkate alınmaktadır. Önerilen bu model, geliştirilen beş farklı parçadan ve dokuz farklı olmak üzere toplamda on bir makineden oluşan bir örnek problem üzerinde uygulanmaktadır. Bu problemin çözümünde GAMS optimizasyon programı kullanılmış olup bir saniyeden daha kısa bir sürede toplam tasarım maliyetini en küçükleyen hücre tasarımı sonuçları ortaya çıkmaktadır.
\end{abstract}

Anahtar Kelimeler: Hücresel üretim sistemleri, Hücre tasarımı, Optimizasyon, Matematik programlama modeli

\begin{abstract}
Cellular manufacturing systems are systems based on the production of similar processes in similar environments which are used in order to enable companies to adapt to constantly developing technology and competition. With the efficient establishment and design of cellular production systems, processes can be realized faster and with less cost. In this article, a mathematical programming model which aims the optimum total design cost involving production cost, setup cost of machines, maintenance cost of machines and personnel cost is developed. In the model, various constraints such as capacities of machines, minimum number of machines required to form a cell, maximum number of cells each machine type can be assigned to, minimum number of machines for which parts can be processed, maximum number of machines for which parts can be processed and type of machines that cannot process parts are considered. This proposed model is applied on a developed sample problem consisting of five different parts and total eleven machines with nine different machines. Using GAMS optimization program to solve this problem, the results of the cells design which make the total design cost optimum are ensured in less than one second.
\end{abstract}

Keywords: Cellular manufacturing systems, Cell design, Optimization, Mathematical programming model

\section{GÍRIŞ}

Günümüz şartlarında teknolojinin gelişmesi ile birlikte rekabet sürekli artmakta ve dolayısıyla sistemler kendilerini sürekli geliştirmek zorunda kalmaktadır. Bu zorunluluk nedeniyle ortaya çıkan sistemlerden birisi de hücresel üretim sistemleridir. Üretkenliği artırmak ve süreç esnekliğini geliştirmek için hücresel imalat sistemlerine olan ilgi artmaktadır [1]. Hücresel üretim, hem maliyetlerin azaltılmasına hem de küçük ve orta ölçekli üretim ortamında sistem esnekliğinin artırılmasına yönelik bir üretim yaklaşımıdır [2]. Hücresel üretim sistemleri benzer parça ailelerinin kendilerine has atanmış olan makine ortamlarında üretilme esasına dayanmaktadır. Bu şekilde herhangi bir değişim anında tüm sistemin değiştirilmesine gerek kalmadan ilgili alanda değişime imkân sağlanmaktadır. 
Hücresel üretim sistemi kavramı orta hacimlerde üretim yapan ve benzer iş akışlarından oluşan üretim sistemlerinin içine uygulanarak sistem verimliliği arttırılabilir ve çeşitli maliyet kalemlerinde kazançlar elde edilebilir. Hücrelerin tasarımı konusu genellikle üretim özellikleri yakın olan parçaların ve bu parçalara ilişkin makinelerin gruplandırılması ile ilgilenmektedir. Üretim verileri ve işlem karakteristikleri gibi birçok faktörün dikkate alınması gerekliliği nedeniyle hücresel üretim sistemlerinin tasarımı karmaşıktır [1]. Ancak, doğru bir hücre tasarımı çalışmasıyla işlemlerin daha hızlı bir şekilde ve daha az maliyet ile gerçekleştirilmesi sağlanabilmektedir. Örneğin; hücresel üretim sistemine geçen bir çalışmada [3], böyle bir sisteme geçilmesi ile maliyetlerinin önceki kullanılan sistemdeki maliyetlere göre azaldığ görülmektedir [3]. Ayrıca, optimum hücre tasarımı, işlem süresi, malzeme taşıma maliyeti, işçilik maliyeti ve süreç içi stok miktarı gibi kalemlerin minimum olmasını sağlayabilmektedir [4].

Hücresel üretim sistemlerinin tasarımı ile ilgili literatürden bazı makaleler aşağıdaki gibidir: Srinivasan vd. [5], parça aileleri problemi için girdisi bir benzerlik katsayısı matrisi olan bir atama modeli sunmuşlardır. Shafer ve Rogers [6], hücre formasyon problemi için üç farklı durumu dikkate alan amaç programlama modelleri geliştirmişlerdir. Bu durumlar, bütünüyle yeni bir sistem kurmak ve yeni ekipmanlar almak, sistemi mevcut ekipmanları kullanarak yeniden düzenlemek ve sistemi mevcut ekipmanları ya da bazı yeni ekipmanları kullanarak yeniden düzenlemek şeklindedir. Adil vd. [7] çalışmalarında, yatırım ve operasyonel maliyetleri ve ayrıca makinelerin boşta kalma süresi, parça envanteri ve teslim tarihlerine göre parçaların erken veya geç bitirilmesi gibi bazı durumları da dikkate alarak karma tamsayılı bir matematik programlama modeli geliştirmişlerdir. Heragu ve Chen [8], kaynak kullanımı ve alternatif rotalama gibi durumları dikkate alan hücresel üretim sistemlerinin tasarımı problemi için matematik bir model önermişlerdir. Wang [9] çalışmasında, makine hücresi ve parça ailesi formasyonu için doğrusal bir atama algoritması sunmuştur. Öztürk ve Öztürk [10] çalışmalarında, makinelerin ve parçaların eş zamanlı olarak hücrelere atandığ 1 hücre oluşturma problemini çözmek için bir yapay sinir ağ önermişlerdir. Prabhaharan vd. [11] toplam hücre yük değişimini ve toplam hücreler arası hareketleri minimum yapma amaçlı makine gruplama problemini ele almışlardır. Defersha ve Chen [12], dinamik hücre konfigürasyonu, alternatif rotalama, operasyon sıralaması, makine kapasitesi, hücreler arasında iş yükünün dengelenmesi, operasyon maliyeti, taşeron maliyeti, takım maliyeti, hazırlık maliyeti ve hücre büyüklüğü limiti gibi çeşitli faktörleri dikkate alan hücresel üretim sistemlerinin tasarımı problemi için bir matematik programlama modeli geliştirmişılerdir.
Ozturk vd. [13] makinelerin ve parçaların aynı anda hücrelere atanmasını sağlayan bir yapay sinir ağı yaklaşımı önererek bu yaklaşımlarını literatürden bazı veri setlerinden faydalanarak genetik algoritma, tabu arama, tavlama benzetimi gibi bazı tekniklerle karşılaştırmışlardır. Mahdavi vd. [14], hücre kullanımı kavramına dayalı hücre formasyon problemi için bir matematik model önermişlerdir. Ameli ve Arkat [15], parçaların proses sıralarını ve üretim hacimlerini dikkate alarak makine hücrelerinin konfigürasyon problemini ele almışlardır. Ayrıca, makine güvenilirliği ve parça türleri için alternatif proses rotalarını ele alarak doğrusal bir tamsayı programlama modeli geliştirmişlerdir. Fan ve Feng [16], hücreler arası ve hücreler içi malzeme maliyeti, makine yer değiştirme maliyeti, işçi çalıştırma süresi ve işçi maaşı gibi kalemleri ele alarak doğrusal olmayan karma tamsayılı programlama modeli geliştirmişlerdir. Raminfar vd. [2] hücresel üretim sistemleri için hücre formasyon ve üretim planlama problemlerini aynı anda çözmek için bir dinamik deterministik matematik model sunmuşlardır. Bu modelin amacı hücrelerarası malzeme taşıma maliyetini, makine işletme maliyetini, hazırlık maliyetini ve parça stok maliyetini minimum yapmaktır. Erenay vd. [17] çalışmalarında, katmanlı bir hücresel sistemi dikkate alarak stokastik bir hücresel tasarım konusuna yönelmişlerdir. Paydar ve Saidi-Mehrabad [18] çalışmalarında, sanal üretim hücrelerinin tasarımında müşteri talepleri ve makine kapasiteleri gibi kritik parametreleri göz önünde bulundurarak tedarik, üretim ve dağıtım planlamasının entegrasyonu için iki amaçlı olasılıksal optimizasyon matematik programlama modeli geliştirmişlerdir. Rafiei vd. [19]'nin çalışmalarında, hücreler arası hareketler için yığın büyüklüklerinin optimize edilmesini dikkate alan dinamik bir hücresel üretim sisteminin tasarlanması problemi ele alınmaktadır. Makine satın alma, operasyon, hücreler arası hareketler, makinelerin transfer edilmesi gibi durumların maliyetinin minimum yapılması ve proses içi envanterin minimum yapılması şeklinde amaç fonksiyon kalemlerini içeren iki amaçlı karma tamsayılı doğrusal olmayan bir programlama modeli önerilmiştir. Aghajani vd. [20]'nin çalışmalarında, kanban mekanizması tarafindan kontrol edilen hücresel üretim sistemleri incelenmiş olup kusur oranları, elde bulundurma maliyeti, hazırlık maliyeti gibi kalemlerin toplam sistem maliyetine olan etkisi değerlendirilerek parçacık sürü optimizasyonu, tavlama benzetimi gibi meta sezgisel algoritmalar önerilmiştir. Alhourani [21] çalışmasında, makine kapasitesi, makine güvenilirliği ve makine çoğaltılması gibi durumları değerlendirerek uygun makine gruplanması ve toplam maliyetin minimizasyonu problemini ele almıştır.

Aljuneidi ve Bulgak [22], etkin bir geri dönüşüm ve yeniden üretim ağı için yeniden konfigüre edilebilir hücresel üretim sistemlerinin ve hibrid üretim-yeniden üretim sistemlerinin eş zamanlı bir incelemesini 
sunmuşlardır ve sürdürülebilir üretim sistemleri için tasarım optimizasyonu, analizi ve süreç planlama durumları için bütünleşik bir yaklaşım önermişlerdir. Feng vd. [23], işçi atama ve hücre formasyon problemlerini birlikte dikkate alarak makinelerin, parçaların ve işçilerin optimum yerleşimi için doğrusal bir model önermişlerdir. Kazemi vd. [24], parçaların işlenmesi, hücreler arası hareketler, makinelerin kurulumu / kaldırılması ve üretim kaybı gibi çeşitli durumların maliyetlerini göz önünde bulunduran dinamik hücresel üretim sistemlerinin tasarımı konusuna karma tamsayılı lineer olmayan bir matematik programlama modeli önermişlerdir. Sadeghi vd. [25] çalışmalarında, hücre formasyonu, operatör ataması ve hücreler arası yerleşim konularını aynı anda çözmek için bir matematik programlama modeli geliştirmişlerdir. Soolaki ve Arkat [26]'in hücre tasarımı çalışmasında ürünlerin üretim süreci ve uygun tesis yeri seçimi için coğrafik olarak dağıtılmış bir tasarım önerilmiştir. Feng vd. [27] çalışmalarında, bütünleşik olarak hücre tasarım ve yerleşim problemini incelemişlerdir. $\mathrm{Bu}$ nedenle, amaç fonksiyonu, malzeme taşıma, operasyon ve taşerona yaptırma maliyetlerinden oluşan karma tamsayılı doğrusal programlama modeli geliştirilmiş olup üretim planlama, alternatif rotalama ve makine çoğaltımı gibi tasarım kriterleri dikkate alınmıştır. Maleki vd. [28] çalışmalarında, hücresel teknoloji içerisinde makinelerin ve parçaların gruplandırılması problemi için çok amaçlı bir matematik programlama modeli geliştirmişlerdir. Geliştirilen bu modelde, hem hücreler içi ve hücreler arası taşıma maliyetinin minimum yapılması hem de makinelerin yeri bakımından hücrelere parçaların atanmasının öneminin maksimum yapılması dikkate alınmaktadır. Her hücre için her parçanın ağırlığı analitik hiyerarşi prosesi ile belirlenmektedir. Mahmoodian vd. [29] çalışmalarında, hücresel üretim tasarım problemi için parçacık sürü optimizasyon algoritmasını ve sinir ağlarını içeren bir yaklaşım geliştirmişlerdir. Shashikumar vd. [30] çalışmalarında, hücre tasarım problemi için genetik algoritma ve üyelik indeksi ile birlikte bazı sezgisel teknikleri de içeren bütünleşik bir yaklaşım geliştirmişlerdir. Sezgisel teknikler, genetik algoritma için başlangıç popülasyonunun belirlenmesinde kullanılırken, genetik algoritma hücrelere makine atanma sonuçlarının en iyilenmesinde, üyelik indeksi ise hücrelere parçaları atamada kullanılmaktadır.

Bu çalışmada, en uygun hücre tasarımını belirlemek için matematik programlama modeli geliştirilmektedir. Toplam maliyeti minimum yapmayı hedefleyen programın amacinda üretim maliyetleri, makinelerin hazırlık maliyetleri, makinelerin bakım maliyetleri ve personel maliyetleri dikkate alınmaktadır. Geliştirilen modelde, makinelerin kapasiteleri, hücreyi oluşturmak için gerekli olan minimum makine sayısı, her bir parça için en az kaç işlem göreceği ve parçaların işlem göremeyeceği makineler gibi çeşitli kısıtlar sözkonusudur. Çalışmada optimum hücre tasarımına göre makinelerin hangi hücrelere atandığı ve parçaların hangi makinelerde işlendiği optimum toplam maliyet ile birlikte görülebilmektedir.

\section{MATERYAL VE METOT}

$\mathrm{Bu}$ çalışmada, tamsayılı bir matematik model geliştirilmiş olup aşağıda indisleri, karar değişkenleri, parametreleri, amaç fonksiyonu ve kısıtları detaylı olarak yer almaktadır:

Indisler

\begin{tabular}{lll}
\hline$i$ & parça indisi & $\mathrm{i}: 1, \ldots, \mathrm{I}$ \\
$m$ & makine indisi & $\mathrm{m}: 1, \ldots, \mathrm{M}$ \\
$h$ & hücre indisi & $\mathrm{h}: 1, \ldots, \mathrm{H}$
\end{tabular}

\section{Parametreler}

$n_{m}: \quad$ m türünden makinelerin sayısı

$M x_{m}$ : $\quad$ m. makinenin para birimi cinsinden

bakım maliyeti

$l_{h m}: \quad$ h. hücreye atanan m. makinenin

hücre içerisindeki hazırlık maliyeti

$k_{m}$ : $\quad$ m. makinenin kapasitesi

$l t$ : hücrenin açılması için gereken minimum makine sayısı

$o_{m}: \quad \mathrm{m}$ türünden makine için gereken personel sayısı

pers: $\quad$ personel maliyeti

$c_{i m}$ : i. parçanın m. makinedeki birim yapılma maliyeti

$t_{i m}: \quad$ i. parçanın m. makinedeki birim yapılma süresi

$d_{i}: \quad$ i. parçaya dair gelen talep

enazi: parçaların en az kaç makinede işlenmesi gerektiğini gösteren tamsayı

encok $_{i}$ : parçaların en çok kaç makinede işlenmesi gerektiğini gösteren tamsayı

E: bazı makinelerde işlem göremeyeceği belirtilen parçaların kümesi

$F$ : belirtilen parçaları işleyemeyen makinelerin bulunduğu küme

$W W: \quad \quad$ çok büyük pozitif bir tamsayı

\section{$\underline{\text { Karar Değișkenleri }}$}

$\operatorname{prtmcn}_{i h m}=\left\{\begin{array}{c}1, i . p a r c ̧ a h . h u ̈ c r e d e k i \text { m. makineye atanırsa } \\ 0, \text { aksi halde }\end{array}\right.$

cellmcn $_{h m}=\left\{\begin{array}{c}1, h . \text { hücreye } m . \text { makine atanırsa } \\ 0, \text { aksi halde }\end{array}\right.$

Amaç Fonksiyonu

$$
\operatorname{Min}\left(\begin{array}{l}
\sum_{h}^{H} \sum_{m}^{M} \text { cellmcn }_{h m} \cdot l_{h m} \cdot n_{m}+\sum_{h}^{H} \sum_{m}^{M} \text { cellmcn } n_{h m} \cdot M x_{m} \cdot n_{m}+ \\
+\sum_{i}^{I} \sum_{h}^{H} \sum_{m}^{M} \text { prtmcn }_{i h m} \cdot t_{i m} \cdot d_{i} \cdot c_{i m}+\sum_{h}^{H} \sum_{m}^{M} \text { cellmcn }_{h m} \cdot o_{m} \cdot \text { pers }
\end{array}\right)
$$

Eşitlik (1)'de toplam maliyeti minimum yapan amaç fonksiyonu formülasyonu sunulmaktadır. $\mathrm{Bu}$ fonksiyonun ilk kaleminde makinelerin hazırlık 
maliyeti, ikinci kaleminde makinelerin bakım maliyeti, üçüncü kaleminde üretim maliyeti ve dördüncü kaleminde personel maliyeti yer almaktadır.

\section{Kisit Denklemleri}

Eşitlik (2), tüm sistemde toplam makinelerin kapasitesinin gelen talebi karşılamak için en az gelen talep kadar olmasını sağlayan denklemdir. Diğer bir ifade ile bu kısıt ile talebin kapasiteyi aşmaması sağlanmaktadır.

$$
\sum_{h}^{H} \sum_{m}^{M} \text { cellmcn }_{h m} \cdot k_{m} \cdot n_{m} \geq \sum_{i}^{I} \sum_{h}^{H} \sum_{m}^{M} \text { prtmcn }_{i h m} . t_{i m} \cdot d_{i}
$$

Eşitlik (3), bir hücreye atanan makine varsa o makineye parça atanmasını sağlayan kısıt denklemidir.

$$
\sum_{i}^{I} \operatorname{prtmcn}_{i h m} \leq \text { cellmcn }_{h m} \cdot W W \quad, \forall h, \forall m
$$

Eşitlik (4), hücrelerin açılabilmesi için hücrelerin içermesi gereken minimum makine sayısını gösteren denklemdir.

$$
\sum_{m}^{M} \text { cellmcn }_{h m} \geq l t \quad, \forall h
$$

Eşitlik (5), her makine türünün en fazla sayısı kadar hücreye atanabileceğini gösteren kısıttır.

$$
\sum_{h}^{H} \text { cellmcn }_{h m} \leq n_{m} \quad, \forall m
$$

Eşitlik (6), parçaların en az kaç makinede işlenmesi gerektiğini gösteren kısıt denklemidir.

$$
\sum_{h}^{H} \sum_{m}^{M} \operatorname{prtmcn}_{i h m} \geq \operatorname{enaz}_{i} \quad, \forall i
$$

Eşitlik (7), parçaların en fazla kaç makinede işlenmesi gerektiğini gösteren kısıt denklemidir.

$\sum_{h}^{H} \sum_{m}^{M}$ prtmcn $_{i h m} \leq$ encok $_{i} \quad, \forall i$

Eşitlik (8), hangi parçaların hangi makinelerde işlem göremeyeceğini belirten kısıt denklemidir.

prtmcn $_{r h p}+$ prtmcn $_{r h q}=0 \quad, \forall r, r \in E, \quad \forall h, \quad \forall p, \forall q, p, q \in F$

Eşitlik (8)'e göre, örneğin; parça 1'in makine 3 ve makine 5'te işlem göremeyeceğinin belirtilmesi durumunda bu kısıt denklemi şu şekilde oluşmaktadır: prtmcn $_{1 h 3}+$ prtmcn $_{1 h 5}=0 \quad, \forall h$

Eşitlikler (9) ve (10), karar değişkenlerinin ikili tamsayılı olduğunu göstermektedir.

$$
\begin{array}{ll}
\text { prtmcn }_{\text {ihm }} \in\{0,1\} & , \forall i, \forall h, \forall m \\
\text { cellmcn }_{h m} \in\{0,1\} & , \forall h, \forall m
\end{array}
$$

\section{BULGULAR}

\subsection{Geliştirilen Modelin Girdileri}

Geliştirilen matematik programlama modeli için geliştirilen örnek problemde 5 farklı parça ve 2 farklı hücre dikkate alınmaktadır. Ayrıca, sistemde 9 farklı türde olmak üzere toplamda 11 makine ele alınmıştır. Sisteme gelen parça talepleri ise şu şekildedir: Parçal için 810 , parça2 için 650 , parça3 için 750 , parça4 için 800 ve parça 5 için 950 parçadır. Bunlardan başka, bir hücrenin açılması için gereken minimum makine sayısı 2, personel maliyeti 2000 para birimi ve WW çok büyük bir pozitif tamsayı (10000000) olarak tanımlanmıştır. Tablo 1'de sistemdeki makineler ile ilgili girdi parametreleri yer almaktadır. Tablo 2, parçaların makinelerdeki para birimi cinsinden yapılma maliyetlerini göstermektedir. Tablo 3'te parçaların makinelerdeki yapılma süreleri yer alırken Tablo 4'te ise hücrelerde yer alan makinelerin para birimi cinsinden hazırlı maliyetleri toplamı görülmektedir. Tablo 5'te parçaların en az ve en fazla işlem görebilecekleri makine sayıları yer almaktadır. Ayrıca, Tablo 6'da bazı parçalar için işlem göremeyecekleri makine türleri sunulmaktadır.

Tablo 1. Makineler için girdi parametreleri

\begin{tabular}{|c|c|c|c|c|}
\hline $\begin{array}{c}\text { Makine } \\
\text { türü }\end{array}$ & $\begin{array}{c}\text { Makine } \\
\text { türü } \\
\text { sayısı }\end{array}$ & $\begin{array}{c}\text { Gereken } \\
\text { personel } \\
\text { sayısı }\end{array}$ & $\begin{array}{c}\text { Makine } \\
\text { bakım } \\
\text { maliyeti } \\
\text { (para } \\
\text { birimi) }\end{array}$ & $\begin{array}{c}\text { Makine } \\
\text { kasitesi } \\
\text { (saat) }\end{array}$ \\
\hline Makine1 & 2 & 1 & 9850 & 1250 \\
\hline Makine2 & 1 & 2 & 10700 & 1100 \\
\hline Makine3 & 1 & 1 & 21950 & 1400 \\
\hline Makine4 & 1 & 1 & 10500 & 1350 \\
\hline Makine5 & 1 & 3 & 35060 & 1500 \\
\hline Makine6 & 1 & 1 & 12950 & 1850 \\
\hline Makine7 & 2 & 1 & 25020 & 1100 \\
\hline Makine8 & 1 & 1 & 11500 & 1000 \\
\hline Makine9 & 1 & 1 & 15000 & 1150 \\
\hline
\end{tabular}


Tablo 2. Parçaların makinelerdeki para birimi olarak yapılma maliyetleri

\begin{tabular}{|c|c|c|c|c|c|}
\hline $\begin{array}{c}\text { Makine } \\
\text { türü }\end{array}$ & $\begin{array}{c}\text { Parça } \\
\mathbf{1}\end{array}$ & $\begin{array}{c}\text { Parça } \\
\mathbf{2}\end{array}$ & $\begin{array}{c}\text { Parça } \\
\mathbf{3}\end{array}$ & $\begin{array}{c}\text { Parça } \\
\mathbf{4}\end{array}$ & $\begin{array}{c}\text { Parça } \\
\mathbf{5}\end{array}$ \\
\hline $\begin{array}{c}\text { Makine } \\
1\end{array}$ & 5 & 4 & 2 & 5 & 3 \\
\hline $\begin{array}{c}\text { Makine } \\
2\end{array}$ & 7 & 6 & 4 & 7 & 6 \\
\hline $\begin{array}{c}\text { Makine } \\
3\end{array}$ & 9 & 5 & 3 & 6 & 4 \\
\hline $\begin{array}{c}\text { Makine } \\
4\end{array}$ & 11 & 2 & 2 & 4 & 2 \\
\hline $\begin{array}{c}\text { Makine } \\
5\end{array}$ & 8 & 7 & 6 & 6 & 7 \\
\hline $\begin{array}{c}\text { Makine } \\
6\end{array}$ & 7 & 3 & 5 & 8 & 3 \\
\hline $\begin{array}{c}\text { Makine } \\
7\end{array}$ & 7 & 5 & 6 & 9 & 8 \\
\hline $\begin{array}{c}\text { Makine } \\
8\end{array}$ & 9 & 6 & 9 & 7 & 6 \\
\hline $\begin{array}{c}\text { Makine } \\
9\end{array}$ & 10 & 9 & 7 & 8 & 10 \\
\hline
\end{tabular}

Tablo 3. Parçaların makinelerdeki saat cinsinden yapılma süreleri

\begin{tabular}{|c|c|c|c|c|c|}
\hline $\begin{array}{c}\text { Makine } \\
\text { türü }\end{array}$ & $\mathbf{1}$ & $\mathbf{2}$ & $\mathbf{3}$ & $\mathbf{4}$ & $\mathbf{5}$ \\
\hline $\begin{array}{c}\text { Makine } \\
1\end{array}$ & 0,34 & 0,68 & 0,98 & 0 & 0,72 \\
\hline $\begin{array}{c}\text { Makine } \\
2\end{array}$ & 0,91 & 0,97 & 0,97 & 0,97 & 0,65 \\
\hline $\begin{array}{c}\text { Makine } \\
3\end{array}$ & 0 & 0 & 0,83 & 0,89 & 0,90 \\
\hline $\begin{array}{c}\text { Makine } \\
4\end{array}$ & 0,79 & 0,77 & 0 & 0,52 & 0,77 \\
\hline $\begin{array}{c}\text { Makine } \\
5\end{array}$ & 0 & 0,52 & 0,88 & 0,58 & 0,84 \\
\hline $\begin{array}{c}\text { Makine } \\
6\end{array}$ & 0,81 & 0,77 & 0,97 & 0,67 & 0,54 \\
\hline $\begin{array}{c}\text { Makine } \\
7\end{array}$ & 0,75 & 0,80 & 0,85 & 0,89 & 0,85 \\
\hline $\begin{array}{c}\text { Makine } \\
8\end{array}$ & 0,80 & 0,66 & 0 & 0,77 & 0,87 \\
\hline $\begin{array}{c}\text { Makine } \\
9\end{array}$ & 0,85 & 0,90 & 0 & 0,69 & 0,87 \\
\hline
\end{tabular}

Tablo 4. Hücrelerdeki makinelerin para birimi olarak hazırlık maliyetleri toplamı

\begin{tabular}{|l|l|l|}
\hline Makine türü & Hücre1 & Hücre2 \\
\hline Makine1 & 1100 & 1200 \\
\hline Makine2 & 1600 & 1400 \\
\hline Makine3 & 1150 & 1250 \\
\hline Makine4 & 1120 & 1410 \\
\hline Makine5 & 1250 & 1500 \\
\hline Makine6 & 1380 & 1140 \\
\hline Makine7 & 1400 & 1150 \\
\hline Makine8 & 1500 & 1800 \\
\hline Makine9 & 1800 & 1500 \\
\hline
\end{tabular}

Tablo 5. Parçaların en az ve en fazla işlem görebilecekleri makine sayısı

\begin{tabular}{|c|c|c|}
\hline $\begin{array}{c}\text { Parça } \\
\text { türü }\end{array}$ & $\begin{array}{c}\text { En az işlem } \\
\text { görebileceği } \\
\text { makine sayısı }\end{array}$ & $\begin{array}{c}\text { En fazla işlem } \\
\text { görebileceği } \\
\text { makine sayısı }\end{array}$ \\
\hline Parça1 & 3 & 7 \\
\hline Parça2 & 4 & 8 \\
\hline Parça3 & 3 & 6 \\
\hline Parça4 & 4 & 7 \\
\hline Parça5 & 2 & 5 \\
\hline
\end{tabular}

Tablo 6. Parçaların işlem göremeyecekleri makine türleri

\begin{tabular}{|c|c|}
\hline Parça türü & $\begin{array}{c}\text { İşlem göremeyeceği makine } \\
\text { türüi }\end{array}$ \\
\hline Parça1 & Makineler 3 ve 5 \\
\hline Parça2 & Makine 3 \\
\hline Parça3 & Makineler 4, 8 ve 9 \\
\hline Parça4 & Makine 1 \\
\hline
\end{tabular}

\subsection{Geliștirilen Modelin Sonuçları}

Dikkate alınan bu problemin çözümü için GAMS 23.5 optimizasyon programı kullanılmıştır. Bu problem, Intel(R) Core(TM) i5 CPU @ $2.53 \mathrm{GHz}, 2.53 \mathrm{GHz}$ işlemcili ve 8GB RAM'i olan bir bilgisayarda 1 saniyeden daha kısa bir sürede çözümlenmektedir. Problemin minimum toplam maliyeti 147872,20 para birimi olarak elde edilmiştir. Tablo 7'de açılacak olan iki hücreye hangi makinelerin atandığı görülmektedir. Tablo 8'de ise bu hücrelerdeki hangi makinelere hangi parçaların atandığı yer almaktadır. 
Tablo 7. Hücrelere makinelerin atanması

\begin{tabular}{|c|c|c|}
\hline $\begin{array}{c}\text { Makine } \\
\text { türü }\end{array}$ & Hücre1 & Hücre2 \\
\hline Makine1 & 1 & 1 \\
\hline Makine2 & 0 & 1 \\
\hline Makine3 & 0 & 0 \\
\hline Makine4 & 1 & 0 \\
\hline Makine5 & 0 & 0 \\
\hline Makine6 & 1 & 0 \\
\hline Makine7 & 0 & 0 \\
\hline Makine8 & 0 & 1 \\
\hline Makine9 & 0 & 0 \\
\hline
\end{tabular}

Tablo 8. Hücrelerdeki makinelere parçaların atanması

\begin{tabular}{|l|l|l|l|l|l|l|l|l|l|}
\hline & \multicolumn{7}{|c|}{ Makine Numarası } \\
\cline { 2 - 9 } & $\mathbf{1}$ & $\mathbf{2}$ & $\mathbf{3}$ & $\mathbf{4}$ & $\mathbf{5}$ & $\mathbf{6}$ & $\mathbf{7}$ & $\mathbf{8}$ & $\mathbf{9}$ \\
\hline $\begin{array}{l}\text { Parça1/ } \\
\text { Hücre1 }\end{array}$ & 1 & 0 & 0 & 0 & 0 & 1 & 0 & 0 & 0 \\
\hline $\begin{array}{l}\text { Parça1/ } \\
\text { Hücre2 }\end{array}$ & 1 & 0 & 0 & 0 & 0 & 0 & 0 & 0 & 0 \\
\hline $\begin{array}{l}\text { Parça2/ } \\
\text { Hücre1 }\end{array}$ & 1 & 0 & 0 & 1 & 0 & 1 & 0 & 0 & 0 \\
\hline $\begin{array}{l}\text { Parça2/ } \\
\text { Hücre2 }\end{array}$ & 1 & 0 & 0 & 0 & 0 & 0 & 0 & 0 & 0 \\
\hline $\begin{array}{l}\text { Parça3/ } \\
\text { Hücre1 }\end{array}$ & 1 & 0 & 0 & 0 & 0 & 0 & 0 & 0 & 0 \\
\hline $\begin{array}{l}\text { Parça3/ } \\
\text { Hücre2 }\end{array}$ & 1 & 1 & 0 & 0 & 0 & 0 & 0 & 0 & 0 \\
\hline $\begin{array}{l}\text { Parça4/ } \\
\text { Hücre1 }\end{array}$ & 0 & 0 & 0 & 1 & 0 & 1 & 0 & 0 & 0 \\
\hline $\begin{array}{l}\text { Parça4/ } \\
\text { Hücre2 }\end{array}$ & 0 & 1 & 0 & 0 & 0 & 0 & 0 & 1 & 0 \\
\hline $\begin{array}{l}\text { Parça5/ } \\
\text { Hücre1 }\end{array}$ & 1 & 0 & 0 & 0 & 0 & 1 & 0 & 0 & 0 \\
\hline $\begin{array}{l}\text { Parça5/ } \\
\text { Hücre2 }\end{array}$ & 0 & 0 & 0 & 0 & 0 & 0 & 0 & 0 & 0 \\
\hline
\end{tabular}

\subsection{Duyarlılık Analizi}

$\mathrm{Bu}$ çalışmada, duyarlılık analizi için hücre sayısının değiştirilmesiyle toplam maliyetin nasıl etkileneceği görülebilmektedir. Tablo 9'da ve Şekil 1'de görüldüğü gibi hücre sayısının artırılması ile toplam maliyet artmaktadır.
Tablo 9. Hücre sayısının değişiminin toplam maliyete olan etkisi

\begin{tabular}{|c|c|c|c|}
\hline & 2 Hücreli & 3 Hücreli & 4 Hücreli \\
\hline $\begin{array}{c}\text { Maliyet } \\
\text { (para birimi) }\end{array}$ & 147872,20 & 148053,20 & 188540,70 \\
\hline
\end{tabular}

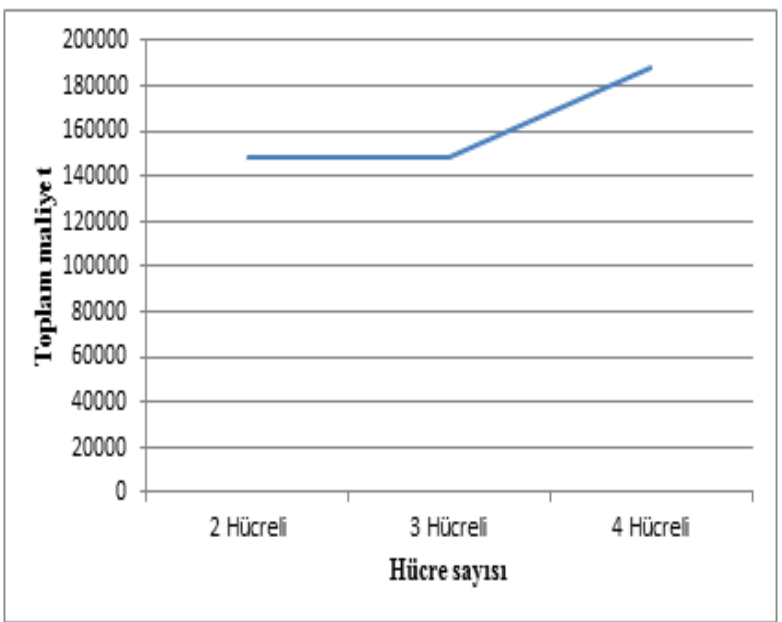

Şekil 1. Hücre sayısının değişiminin toplam maliyete olan etki grafiği

\subsection{Hesaplama Karmaşıklığı Analizi}

$\mathrm{Bu}$ analiz, modele girilen indislerin modelin değişkenlerinin sayısı üzerindeki etkisini göstermektedir. Bu çalışmanın karar değişkenlerini gösteren Tablo 10'da da görüldüğü gibi makine sayıs1, hücre sayısı ve parça sayısı arttıkça analize dair karmaşıklık artabilmektedir. İncelenen probleme dair parça sayısı 5, makine sayısı 11 ve hücre sayısı 2 olarak alındığı için değişken sayısı 132 olmaktadır. Bu analizin etkisini göstermek açısından, örneğin sadece makine sayısının değişiminin toplam değişken sayısı üzerindeki etkisi Şekil 2'de yer almaktadır.

Tablo 10. Çalışmanın modelinin değişken sayısı

\begin{tabular}{|c|c|c|c|c|}
\hline Değişkenler & $\begin{array}{c}\text { Parça } \\
\text { (i) }\end{array}$ & $\begin{array}{c}\text { Makine } \\
\text { (m) }\end{array}$ & $\begin{array}{c}\text { Hücre } \\
\text { (h) }\end{array}$ & Toplam \\
\hline prtmcnihm & $\mathrm{i}$ & $\mathrm{m}$ & $\mathrm{h}$ & $\mathrm{imh}$ \\
\hline cellmcnhm & & $\mathrm{m}$ & $\mathrm{h}$ & $\mathrm{mh}$ \\
\hline Toplam & & & & $\mathrm{mh}(\mathrm{i}+1)$ \\
\hline
\end{tabular}




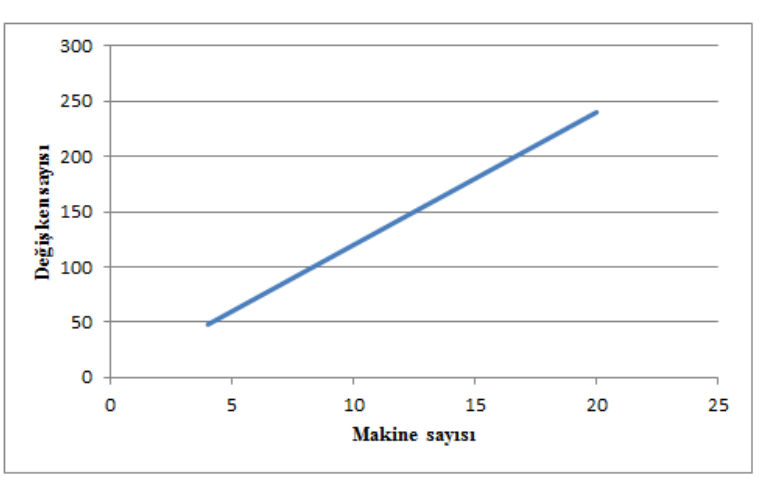

Şekil 2. Makine sayısındaki değişiminin toplam değişken sayısına olan etkisi

\section{SONUÇLAR}

Günümüzde teknolojideki sürekli gelişim ve dolayısıyla artan rekabet ortamı nedeniyle sistemlerin kendilerini geliştirmesi ve güncellemesi artık bir zorunluluk olarak ortaya çıkmaktadır. Bu zorunluluktan doğan sistemlerden birisi de hücresel üretim sistemleridir. $\mathrm{Bu}$ makalede, toplam tasarım maliyetini optimum yapan bir matematik programlama modeli sunulmaktadır. Çalışmanın hedef fonksiyonu olan toplam tasarım maliyeti, üretim maliyeti, makinelerin hazırlık maliyeti, makinelerin bakım maliyeti ve personel maliyeti unsurlarından oluşmaktadır. Ayrıca, önerilen matematik programlama modeli, makinelerin kapasiteleri, hücreleri oluşturmada gereken minimum makine sayısı, her makine türünün en fazla atanabileceği hücre sayısı, parçaların en az ve en fazla kaç makinede işlem görebileceği ve parçaların hangi makinelerde işlem göremeyeceği gibi çeşitli kısıtları dikkate almaktadır. GAMS optimizasyon programı kullanılarak önerilen matematik programlama modelinin çözüm sonuçları, duyarlılık analizi ve ayrıca hesaplama karmaşıklığı analizi makalede sunulmaktadır. Bu çalışma, hücresel üretim sistemlerinde dinamik bir ortam yapısı dikkate alınarak geliştirilebilir. Diğer bir ifade ile gelecek çalışma alanları olarak, parçaların talepleri ile ilgili değişimler veya makinelerde parçaların yapılma süreleri gibi bazı parametrelerin stokastik olduğu durumlar dikkate alınarak hücre tasarım çalışması yapılabilir. Ayrıca, çalışmanın hesaplama karmaşıklığı analizinde modeldeki indislerin sayılarının değişiminin toplam değişken sayısı üzerindeki etkisi sunulmaktadır. Dolayısıyla, incelenen problemin boyutu genişletildiğinde çözüm yöntemi olarak metasezgisel yöntemler de sunulabilir. Son olarak, bu çalışmaya diğer maliyet kalemleri gibi bazı faktörler de dâhil edilerek çalışmanın gerçek bir problem üzerinde uygulaması yapılabilir.

\section{KAYNAKLAR}

[1] Luong, L., He, J., Abhary, K., \& Qiu, L., (2002). A Decision Support System for Cellular Manufacturing System Design. Computers \& Industrial Engineering, 42(2-4), 457-470.
[2] Raminfar, R., Zulkifli, N., Vasili, M., \& Hong, T.S., (2013). An Integrated Model for Production Planning and Cell Formation in Cellular Manufacturing Systems. Journal of Applied Mathematics, 10 pages.

[3] Imran, M., Kang, C., Lee, Y.H., Jahanzaib, M., \& Aziz, H., (2017). Cell Formation in a Cellular Manufacturing System Using Simulation Integrated Hybrid Genetic Algorithm. Computers \& Industrial Engineering, 105, 123-135.

[4] Hazarika, M., \& Laha, D., (2018). Genetic Algorithm Approach for Machine Cell Formation with Alternative Routings. Materials Today: Proceedings, 5(1), 1766-1775.

[5] Srinivasan, G., Narendran, T.T., \& Mahadevan, B., (1990). An Assignment Model for the Partfamilies Problem in Group Technology. International Journal of Production Research, 28(1), 145-152.

[6] Shafer, S.M., \& Rogers, D.F., (1991). A Goal Programming Approach to the Cell Formation Problem. Journal of Operations Management, 10(1), 28-43.

[7] Adil, G.K., Rajamani, D., \& Strong, D., (1993). A Mathematical Model for Cell Formation Considering Investment and Operational Costs. European Journal of Operational Research, 69(3), 330-341.

[8] Heragu, S.S., \& Chen, J.-S., (1998). Optimal Solution of Cellular Manufacturing System Design: Benders' Decomposition Approach. European Journal of Operational Research, 107(1), 175-192.

[9] Wang, J., (2003). Formation of Machine Cells and Part Families in Cellular Manufacturing Systems Using a Linear Assignment Algorithm. Automatica, 39(9), 1607-1615.

[10] Öztürk, G., \& Öztürk, Z.K., (2005). A Competitive Neural Network Approach to Manufacturing Cell Formation. Proceedings of the 35th International Conference on Computers \& Industrial Engineering, Istanbul, Turkey, June 19-22, 1549-1554.

[11] Prabhaharan, G., Muruganandam, A., Asokan, P., \& Girish, B.S., (2005). Machine Cell Formation for Cellular Manufacturing Systems Using an Ant Colony System Approach. Int $J$ Adv Manuf Technol, 25, 1013-1019.

[12] Defersha, F.M., \& Chen, M., (2006). A Comprehensive Mathematical Model for the Design of Cellular Manufacturing Systems. International Journal of Production Economics, 103(2), 767-783.

[13] Ozturk, G., Ozturk, Z.K., \& Islier, A.A., (2006). A Comparison of Competitive Neural Network with Other AI Techniques in Manufacturing Cell Formation. In: Jiao, L., Wang, L., Gao, X., Liu, J., Wu, F. (eds.), Advances in Natural Computation, ICNC 2006, Lecture Notes in 
Computer Science, vol. 4221, Springer, Berlin, Heidelberg, pp. 575-583.

[14] Mahdavi, I., Javadi, B., Fallah-Alipour, K., \& Slomp, J., (2007). Designing a New Mathematical Model for Cellular Manufacturing System Based on Cell Utilization. Applied Mathematics and Computation, 190(1), 662-670.

[15] Ameli, M.S.J., \& Arkat, J., (2008). Cell Formation with Alternative Process Routings and Machine Reliability Consideration. Int $J A d v$ Manuf Technol, 35(7-8), 761-768.

[16] Fan, J., \& Feng, D., (2013). Design of Cellular Manufacturing System with Quasi-dynamic Dual Resource Using Multi-objective GA. International Journal of Production Research, 51(14), 4134-4154.

[17] Erenay, B., Suer, G.A., Huang, J., \& Maddisetty, S., (2015). Comparison of Layered Cellular Manufacturing System Design Approaches. Computers \& Industrial Engineering, 85, 346358.

[18] Paydar, M.M., \& Saidi-Mehrabad, M., (2015). Revised Multi-choice Goal Programming for Integrated Supply Chain Design and Dynamic Virtual Cell Formation with Fuzzy Parameters. International Journal of Computer Integrated Manufacturing, 28(3), 251-265.

[19] Rafiei, H., Rabbani, M., Nazaridoust, B., \& Ramiyani, S.S., (2015). Multi-objective Cell Formation Problem Considering Work-inprocess Minimization. Int $J \quad A d v$ Manuf Technol, 76(9-12), 1947-1955.

[20] Aghajani, M., Keramati, A., TavakkoliMoghaddam, R., \& Mirjavadi, S.S., (2016). A Mathematical Programming Model for Cellular Manufacturing System Controlled by Kanban with Rework Consideration. The International Journal of Advanced Manufacturing Technology, 83(5-8), 1377-1394.

[21] Alhourani, F., (2016). Cellular Manufacturing System Design Considering Machines Reliability and Parts Alternative Process Routings. International Journal of Production Research, 54(3), 846-863.

[22] Aljuneidi, T., \& Bulgak, A.A., (2017). Designing a Cellular Manufacturing System Featuring
Remanufacturing, Recycling, and Disposal Options: A Mathematical Modeling Approach. CIRP Journal of Manufacturing Science and Technology, 19, 25-35.

[23] Feng, H., Da, W., Xi, L., Pan, E., \& Xia, T., (2017). Solving the Integrated Cell Formation and Worker Assignment Problem Using Particle Swarm Optimization and Linear Programming. Computers \& Industrial Engineering, 110, 126137.

[24] Kazemi, M., Gol, S.S., Tavakkoli-Moghaddam, R., Kia, R., \& Khorrami, J., (2017). A Mathematical Model for Assessing the Effects of a Lot Splitting Feature on a Dynamic Cellular Manufacturing System. Production Engineering, 11(4-5), 557-573.

[25] Sadeghi, S., Forghani, M.A., \& Seidi, M., (2017). Integrated Dynamic Cell Formation with Operator Assignment and Inter-cell Layout Problems: A Mathematical Model. Proceedings of the Institution of Mechanical Engineers, Part B: Journal of Engineering Manufacture, 231(9), 1658-1669.

[26] Soolaki, M., \& Arkat, J., (2018). Incorporating Dynamic Cellular Manufacturing into Strategic Supply Chain Design. Int J Adv Manuf Technol, 95(5-8), 2429-2447.

[27] Feng, H., Xi, L., Xia, T., \& Pan, E., (2018). Concurrent Cell Formation and Layout Design Based on Hybrid Approaches. Applied Soft Computing, 66, 346-359.

[28] Maleki, R., Ketabi, S., \& Rafiei, F.M., (2018). Grouping Both Machines and Parts in Cellular Technology by Genetic Algorithm. Journal of Industrial and Production Engineering, 35(2), 91-101.

[29] Mahmoodian, V., Jabbarzadeh, A., Rezazadeh, H., \& Barzinpour, F., (2019). A Novel Intelligent Particle Swarm Optimization Algorithm for Solving Cell Formation Problem. Neural Comput \& Applic, 31(2), 801-815.

[30] Shashikumar, S., Raut, R.D., Narwane, V.S., Gardas, B.B., Narkhede, B.E., \& Awasthi, A., (2019). A Novel Approach to Determine the Cell Formation Using Heuristics Approach. OPSEARCH, 56, 628-656. 